\title{
REWARD MANAGEMENT AND AFFECTIVE COMMITMENT AMONG FACULTIES IN NEPALESE HIGHER EDUCATION
}

\author{
Shreekrishna Kharel*
}

\begin{abstract}
This study tries to investigate the relationship between reward management and affective commitment in faculty in higher educational organizations. This follows a questionnaire survey of variables with a five- point likert and uses regression analysis, coefficient of variation, normality test, factor analysis and Cronbach's alpha for analytical tools. The result shows a positive relationship between reward management and affective commitment. Hence reward management has been seemed to be beneficial for affective commitment. The sectoral sampling adequacy and number of organizations represented in survey might be the small for general implications of the results despite its analytical soundness.
\end{abstract}

Key words: Reward, affective commitment, organization, job, higher education.

\section{INTRODUCTION}

Reward is one of the key levers available to an organization to influence the behaviour, motivation and the commitment of its employees (Dessler, 2010). Reward system is the most effective instrument for enhancing employees' performance. Reward includes all monetary, non-monetary, and psychological payments that an organization provides for its employees (Lawler, 1995). All organizations may not reward their employees equally. Organizational prosperity lies upon the attraction, motivation, development and retention of competent employees (Guth \& Macmillan, 1986). For this purpose, the management has to create an environment in which employees feel truly engaged, committed to the organization's goals and satisfied with their jobs (Lawler, 1995). Encouraging employees to work and be committed to organization toward achieving organizational goals and objectives is one of the most significant challenges for any management team (Floyd \& Wooldridge, 1994). The continuous survival of any work organization requires the cooperation of labour with the other factors of

* Dr. Kharel is a Lecturer, Padam Kanya Campus, Baghbazar, TU. 


\section{REWARD MANAGEMENT AND AFFECTIVE COMMITMENT ...}

production such as land and capital. Organizational commitment refers to the relative strength of an individual's identification with, and involvement in an organization (Mowday, Porter\& Steers, 1982). It is characterized by a strong belief in, and acceptance of the organization's goals and values, a willingness to exert considerable effort on behalf of the organization, and a strong desire to maintain membership in the organization (Porter, 1968). It involves active relationship with the organization in which individuals are willing to give something of them in order to help the organization succeed and prosper (Meyer \& Allen, 1997). According to March and Simeon (1958), real commitment often evolves into an exchange relationship in which individuals attach themselves to the organization in return for certain rewards or outcomes.

Employees' commitment reduces turnover but increases performance (Angle \& Perry, 1981), and employees can only be committed when their needs are met and fulfilled by their organizations. So, the higher is the expectation of workers, the greater is the commitment of employees. On the other hand, the lesser is the expectation of workers the lower is the commitment of the HRs (Martin \& Shawn, 1984). In the study of antecedents of employees' commitment, Mowday, Porter \& Steers (1982) found that more tenured employees are more committed than less tenured employees. They also found that women tend to be more committed as a group than men and those highly educated employees tend to be less committed than less educated HRs. Studies have shown that position; job tenure and organization tenure have a significant relation with employees' development activity and commitment, and that tenure on the job and in the organization has positive relationship with employees' commitment (Kozlowski \& Farr, 1988). Oloko (1972) found that Nigerian workers are committed and motivated to work in organizations managed by fellow Nigerians in which they foresee their opportunity for promotion and advancement as limitless more than organizations that are managed by foreigners where advancement is difficult to achieve. Therefore, there is positive and significant relationship between reward management and commitment, which is the basic philosophy behind which this study is based.

Affective commitment is considered the most beneficialin enhancing organizational effectiveness (Iverson \& Buttigieg, 1999). This type of commitment emphasizes an individual's identification and involvement in the organization (Porter, Steers, Mowday \& Boulian, 1974). Employees high 
in affective commitment demonstrate emotional attachment, identification with and involvement in the organization. This would explain why these employees are less likely to engage in withdrawal or removal behavior and more likely to accept change (Meyer \& Allen, 1997). In addition, in contrast to affectively committed employees, continuance and normatively committed employees demonstrate reduced levels of citizenship behaviors and lack the initiative and plan to perform tasks that go beyond their job descriptions (Shore \& Wayne, 1993). Therefore, affective commitment is correlated more strongly than normative and continuance commitment with measures and actions of absenteeism, and organizational citizenship behavior. Hence this study tries to address following issues:

- Does reward and reward management affect on affective commitment of faculties?

- To what extent are faculties of higher education in Nepal satisfied with the current reward system?

- Are faculties in Nepalese educational organization committed to organizational goals?

\section{OBJECTIVES}

The main objective of this study is to identify the impact of reward management on affective commitment. And specific objectives are as follows:

- to examine the impact of reward management on affective commitment in higher education in Nepal, and

- to assess the need of reward management for making motivated and committed faculties in higher educational organizations.

\section{THEORETICAL FRAMEWORK}

Reward includes all types of material and psychological returns for performing activities in the organization. It is the benefit that attracts an employee's attention and encourages him or her to work efficiently and contribute for productivity of the organization (Caruna \& Calleya, 1998). Employees' performance can be improved by introducing and designed proper reward system, both intrinsic and extrinsic.

There are many variables affecting employee's commitment to organization. Mowday, Porter and Steers (1982) developed a classification related with this issue and questioned effective factors, personal 
characteristics, role and job characteristics, structural characteristics and job experience and work place within this area. The relationship between reward management and affective commitment for this study (figure 1).

Figure 1: Theoretical Framework and Variables

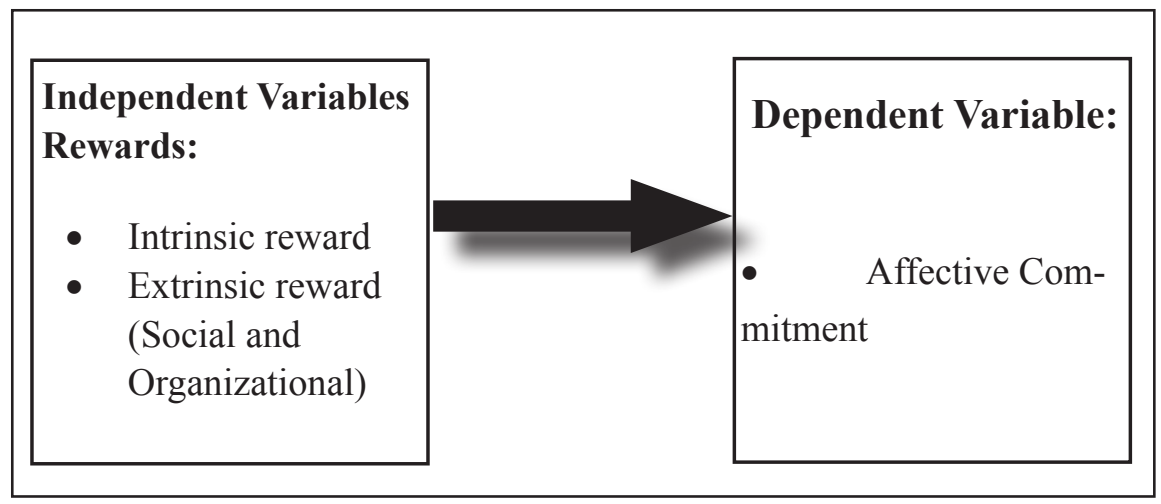

Reward includes all the monetary, non-monetary, and psychological payments that an organization provides for its employees as a return from the organization for their contribution to their organization (Caruna \& Calleya, 1998). Broadly incentives can be divided into intrinsic and extrinsic. On the other hand extrinsic rewards can be social and Organizational.

Under this study affective commitment of faculties towards their organization is the dependent variable. Commitment includes affective, continuance and normative commitment. Affective Commitment emphasizes an individual's identification and involvement in the organization (Porter, Steers, Mowday \& Boulian, 1974).

\section{Hypothesis}

Better rewards management increases the level of affective commitment among faculties.

\section{LIMITATIONS}

The study is fully based on primary data collected through questionnaire. Therefore, the validity of data depends upon the individual perception of the respondents. Similarly it study is confined to faculty of Tribhuvan University which is largest and oldest higher education intuition 
of Nepal. Therefore, the findings of this study may not represent other Nepalese organizational sectors.

\section{METHODOLOGY}

This study follows descriptive and correlation research design based on primary data. The primary data for this study was collected from the faculties of higher education (educational organization) through the questionnaire. This study contains the Nonprobability sampling in which convenience sampling has been adopted. The reasons for selecting this sampling were to represent sample from each category of population. Total number of population from Constituent colleges is 6297(TU Bulletin, 2071) and total number of population from Community based QAA certified college is 339(Ugcnepal.edu.np; 2014). Therefore, at least 569 (total sample size) questionnaires were distributed and collected for the study out of total population 6636 from Constituent college and Community based QAA certified college $(6297+339)$.

The data collected through questionnaires were entered into the database and analyzed through computer software. The mean rating of 5 point Likert scale was calculated so as to determine the level of commitment. Each degree of agreement was given a numerical value from one to five, with 5 being in strong agreement of the statements. The data collected from the respondent were presented, analyzed and interpreted for attaining the objectives of the study. Different statistical tools were used to compare and analyze the results. Mean, regression analysis, coefficient of variation, normality test, factor analysis and Cronbach's Alpha has been calculated between dependent and independent variables separately. Questionnaire survey data were interned into Statistical Package for Social Science (SPSS) version 20 and Microsoft Office Excel 2007.

Basically the validity of the Questionnaire used in this study has been tested by the preliminary testing of the questionnaire in the field. Overall validity of the instruments was determined based on the evaluation and comments by the professors renounced in the respective field of study. The reliability of the perceptual information was ascertained by the computation of the Cronbach's Alpha from the pilot survey. The values of Cronbach's Alpha obtained were more than 0.70. All Cronbach's coefficients exceeded 0.70, which was regarded as acceptable (DeVellis, 2003).Therefore instruments used in this study were valid, reliable and consistent (Table 1). 
Table 1: Cronbach's Alpha of Questionnaire

\begin{tabular}{|l|r|r|}
\hline Variables & No. of items & Cronbach's Alpha \\
\hline Reward Policy and Plan & 14 & 0.918 \\
\hline $\begin{array}{l}\text { Implementation of Reward } \\
\text { Policy \& Plan }\end{array}$ & 37 & 0.974 \\
\hline Evaluation \& Control & 5 & 0.934 \\
\hline Affective commitment & 10 & 0.898 \\
\hline
\end{tabular}

Source: Field survey, 2017.

The value of Cronbach's Alpha [at least $89 \%$ was more than minimum value of $70 \%$ (DeVellis, 2003). It could be concluded that the structure of questionnaire was reliable for this study (Table 1). Profile of respondents according to service year, age group, gender, academic qualification, faculty, job position, level of organization and type of organization (Table 2-9).

Table 2: Service Year of the Respondents

\begin{tabular}{|l|l|l|}
\hline Service Year & Frequency & Percent \\
\hline $1-10$ & 150 & 26.4 \\
$11-20$ & 249 & 43.8 \\
$21-30$ & 123 & 21.6 \\
31 and above & 47 & 8.3 \\
Total & $\mathbf{5 6 9}$ & $\mathbf{1 0 0 . 0}$ \\
\hline
\end{tabular}

Source: Field survey, 2017.

Most of the respondents were in between 11 years to 20 years $(43.8 \%)$ and minimum numbers were in 31 years and above (Table 2 ) for age of respondents (Table 3 ).

Table 3: Age Group of the Respondents

\begin{tabular}{|l|l|l|}
\hline Age Group & Frequency & Percent \\
\hline $27-36$ & 84 & 14.8 \\
$37-46$ & 179 & 31.5 \\
$47-56$ & 228 & 40.1 \\
57 and above & 78 & 13.7 \\
Total & $\mathbf{5 6 9}$ & $\mathbf{1 0 0}$ \\
\hline
\end{tabular}

Source: Field survey, 2017.

The highest numbers of respondents were from age group in between $47-56$ and lowest were aged 57 and above (Table 3). 
Table 4: Gender Status of the Respodents

\begin{tabular}{|l|l|l|}
\hline Gender Group & Frequency & Percent \\
\hline Male & 462 & 81.2 \\
Female & 107 & 18.8 \\
Total & $\mathbf{5 6 9}$ & $\mathbf{1 0 0}$ \\
\hline
\end{tabular}

Source: Field survey, 2017.

Most of the respondents were male (462/569) and female respondents were in minimum number. They were only in 107 numbers (Table 4). The number of respondents according to academic qualification (Table 5).

Table 5: Academic Qualification of the Respondents

\begin{tabular}{|l|l|l|}
\hline Academic Qualification & Frequency & Percent \\
\hline Ph.D. & 85 & 14.9 \\
M.Phil. & 56 & 9.8 \\
Master & 428 & 75.2 \\
Total & $\mathbf{5 6 9}$ & $\mathbf{1 0 0 . 0}$ \\
\hline
\end{tabular}

Source: Field survey, 2017.

The large numbers of respondents were only master's degree holders. They were 428 out of total 569 respondents. A total of 85 were from Ph.D. holders and only 56 were M.Phil. holders (Table 5). The number of respondents and their percentage according to their faculty (Table 6).

Table 6: Faculty Group of the Respondents

\begin{tabular}{|l|l|l|}
\hline Faculty Group & Frequency & Percent \\
\hline Management & 161 & 28.3 \\
\hline Humanities \& Social science & 178 & 31.3 \\
\hline Science \& Technology & 96 & 16.9 \\
\hline Medicine \& Engineering & 75 & 13.2 \\
\hline Education & 43 & 7.6 \\
\hline Law & 16 & 2.8 \\
\hline Total & $\mathbf{5 6 9}$ & $\mathbf{1 0 0 . 0}$ \\
\hline
\end{tabular}

Source: Field survey, 2017.

The large number of respondents were from faculty of Humanities and Social Sciences (178) and lowest number (16) were from law faculty: 161 Management, 96 Science and Technology, 75 Medicine and Engineering, 
43 were from education, and rest 16 were from Law. (Table 6). The job position of the respondents (Table 7).

Table 7: Job Position of the Respondents

\begin{tabular}{|l|l|l|}
\hline Job Position & Frequency & Percent \\
\hline Professor & 44 & 7.7 \\
Reader & 185 & 32.5 \\
Lecturer & 340 & 59.8 \\
Total & $\mathbf{5 6 9}$ & $\mathbf{1 0 0 . 0}$ \\
\hline
\end{tabular}

Source: Field survey, 2017.

The highest number of respondents were lecturer (340) and lowest number were from Professors (44), and readers were 185 (Table 7). The category of organization representing the respondents had been divided into the following two levels (Table 8).

Table 8: Category of Organization and Respondents

\begin{tabular}{|l|l|l|}
\hline Category of Organization & Frequency & Percent \\
\hline University/Central Department & 56 & 9.8 \\
College/Campus & 513 & 90.2 \\
Total & $\mathbf{5 6 9}$ & $\mathbf{1 0 0 . 0}$ \\
\hline
\end{tabular}

Source: Field survey, 2017.

The large number of respondents (513) were from different colleges/ campus and the lowest number were from university and central departments (56) (Table 8). The type of organization used in the study (Table 9).

Table 9: Type of Organization and Respondents

\begin{tabular}{|l|l|l|}
\hline Type of Organization & Frequency & Percent \\
\hline Constituent college & 380 & 66.8 \\
Communitybased QAA certified college & 189 & 33.2 \\
Total & $\mathbf{5 6 9}$ & $\mathbf{1 0 0}$ \\
\hline
\end{tabular}

Source: Field survey, 2017.

The largest number of respondents (380) were from constituent college and 180 respondents are from Community based QAA certified colleges were selected according to sample size calculation (Table 9). 


\section{ANALYSIS}

Factor analysis is a data reduction method, which is very useful method to reduce a large number of variables resulting in data complexity to manageable factors. This study contains 56 statements related with independent variables and number of samples are 569, so respondents were near to 10 times of number of statements. The initial sets of variables should be highly correlated. The value of Kaiser-Meyer-Olkin (KMO) statistics, which takes place a value in between 0 to 1 . Bartlett's Test of Sphericity should be significant. This study has fulfilled the above considerations, so factor analysis was most suitable. There was no hard and fast rule to decide on the cut-off point. However, generally it has been taken to be greater than 0.5 (Chawla \& Sondhi, 2011). All those variables attached to a factor, once the cut-off point has been decided, were used for naming the factors. The result of KMO test (Table 10).

Table 10: KMO and Bartlett's Test

\begin{tabular}{|c|c|c|}
\hline Kaiser-Meyer-Olkin Measure of Sampling Adequacy. & 0.932 \\
\hline \multirow{2}{*}{$\begin{array}{c}\text { Bartlett's Test of } \\
\text { Sphericity }\end{array}$} & Approx. Chi-Square & 20885.359 \\
\cline { 2 - 3 } & df & 1540 \\
\cline { 2 - 3 } & Sig. & .000 \\
\hline
\end{tabular}

Source: Field survey, 2017.

The sample adequacy (KMO measure) was 0.932 which was in highest and above 0.50. Therefore the sample was sufficient for factor analysis. Bartlett's Test of Sphericity was found to be significant at 1 percent level of significance. Hence, factor analysis could be done for given data set. Considering correlation coefficient more than 0.5 , only three factors were loaded namely Job characteristics, pay satisfaction and reward system according to the representation of statements/variables (Table 10). While conducting the linear model fit, first of all there should be Normality test. For the Normality test there should be test of Kolmogorov Smirnov. If the result of this test is insignificant, then it is suitable to go for regression analysis (Table 11).

Table 11: Assumption Test

\begin{tabular}{|l|l|l|}
\hline Variables (Commitment) & Kolmogorov Smirnov & Significance \\
\hline Affective & 1.022 & 0.247 \\
\hline
\end{tabular}

Source: Field survey, 2017. 
This has been seemed to be insignificant at 1 percent level of significant. That means it is suitable for regression analysis (Table 11).

Following model had been used to test the relation between reward management and affective commitment:

$A C=\alpha+\beta_{1} R_{1}+\beta_{2} R_{2}+\beta_{3} R_{3}+\varepsilon$

Where, AC refers to affective commitment,

$\mathrm{R}_{1}$ refers to reward system

$\mathrm{R}_{2}$ refers to job characteristics

$\mathrm{R}_{3}$ refers to pay satisfaction

$\varepsilon$ refers to random error term.

The regression result is found to be as follows:

Table 12: Model Summary

\begin{tabular}{|l|l|l|l|l|}
\hline Model & R & R Square & Adjusted R Square & $\begin{array}{l}\text { Std. Error of } \\
\text { the Estimate }\end{array}$ \\
\hline 1 & $.591^{\mathrm{a}}$ & .349 & .345 & .60883 \\
\hline
\end{tabular}

Source: Field survey, 2017.

Predictors: (Constant), reward system, job characteristics, pay satisfaction.

The model summary has clearly indicated that 34.9 percent of affective commitment was explained by job characteristics, reward system and pay satisfaction. The standard error of estimate was only 0.82490 . So prediction was seemed to be reliable (Table 12).

Table 13: ANOVA $^{\mathrm{a}}$

\begin{tabular}{|l|l|l|l|l|l|}
\hline Model & Sum of Squares & Df & Mean Square & F & Sig. \\
\hline Regression & 112.151 & 3 & 37.384 & 100.852 & $.000^{\mathrm{b}}$ \\
\hline Residual & 209.432 & 565 & .371 & & \\
\hline Total & 321.583 & 568 & & & \\
\hline
\end{tabular}

Source: Field survey, 2017.

The model was significant at 1 percent level of significance as p-value $(0.00)$ was less than level of significance $(0.01)$. So, linear regression model could be used to analyze the data. (Table 13). 
Table 14: Coefficients ${ }^{\text {a }}$ Related with Affective Commitment

\begin{tabular}{|l|c|c|c|c|c|c|c|}
\hline \multirow{2}{*}{ Model } & \multicolumn{2}{|c|}{$\begin{array}{c}\text { Unstandardized } \\
\text { Coefficients }\end{array}$} & $\begin{array}{c}\text { Standardized } \\
\text { Coefficients }\end{array}$ & $\mathbf{t}$ & Sig. & \multicolumn{2}{|c|}{$\begin{array}{c}\text { Collinearity } \\
\text { Statistics }\end{array}$} \\
\cline { 2 - 8 } & $\mathbf{B}$ & $\begin{array}{c}\text { Std. } \\
\text { Error }\end{array}$ & Beta & $\mathbf{B}$ & & Tolerance & VIF \\
\hline (Constant) & 1.505 & .146 & & 10.308 & .000 & & \\
\hline $\begin{array}{l}\text { Pay } \\
\text { satisfaction }\end{array}$ & -.014 & .026 & -.021 & -.525 & .600 & .720 & 1.389 \\
\hline $\begin{array}{l}\text { Job } \\
\text { characteristics }\end{array}$ & .408 & .038 & .389 & 10.658 & .000 & .864 & 1.157 \\
\hline $\begin{array}{l}\text { Reward } \\
\text { system }\end{array}$ & .331 & .041 & .335 & 8.001 & .000 & .657 & 1.522 \\
\hline
\end{tabular}

Source: Field survey, 2017.

Hence $\mathrm{R}^{2}$ value has stated that linear model could be fit or appropriate. Pay satisfaction did not impact on affective commitment. Job characteristics had positive impact on affective commitment as P value 0.00 was less than alpha 5 percent. Further when job characteristics increase by one point, then affective commitment was expected to increase by 0.408 point. Reward system had also positive impact on affective commitment as $\mathrm{P}$ value 0.00 was less than alpha 5 percent. Further when reward system increases by one point, then affective commitment has to be expected to increase by 0.331 point. TheVIF was less than 10 . There was not problem of Multicollinearity (Table 14).

\section{FINDINGS}

The present study focuses on the position of organizational rewards management and affective commitment in higher education. There was no problem of multicollinearity because VIF value was very low (almost near to 1 and not more than 2) which was less than 10 in each independent and dependent variables. And higher value of Cronbach Alpha of this study had identified that the statements were more reliable. Similarly factor analysis of independent variables had identified that only three factors were loaded namely job characteristics, pay satisfaction and reward system according to the representation of statements/variables. Assumption Test (Normality) had indicated that there was no significance in dependent variables (affective commitment). Therefore, it was better to go for regression analysis for this study. Hence summarized findings of the regression analysis of the study were: 
Table 15: Summary of regression analysis

\begin{tabular}{|l|l|l|}
\hline $\begin{array}{l}\text { Independent } \\
\text { variable }\end{array}$ & $\begin{array}{l}\text { Dependent variable } \\
\text { (Affective commitment) }\end{array}$ & $\begin{array}{l}\text { Effect in } \\
\text { aggregate }\end{array}$ \\
\hline Pay satisfaction & insignificant & \multirow{2}{*}{ significant } \\
\hline Job characteristics & significant & \\
\hline Reward system & significant & \\
\hline
\end{tabular}

Source: Field survey, 2017.

The pay satisfaction serves as independent variable with no significant effect on dependent variable. Job characteristics had significant effect. Another independent variable was reward system, which had significant effect. In aggregate, the regression analysis had stated that there was significant effect of reward management as an independent variable on affective commitment (dependent variable) (Table 15).

The hypothesis was formulated to test effect of reward management on affective commitment. Out of the independent variables, job characteristics and reward system were found to be significant at 1 percent level of significance, whereas pay satisfaction was found to be insignificant. It could be concluded that the hypothesis was accepted at 1 percent level of significance.

\section{CONCLUSION}

Present study is seemed to be consistent with the study conducted by Malhotra, Budhwar and Prowse (2007), Nawab and Bhatti (2011), Omolayo and Owolabi (2007), Rumpel and Medcof (2006), Tsai and $\mathrm{Wu}$ (2011), Newman and Sheikh (2012) and the study of Lee, Yang and Hambrick (2012). This study did not supported by the study of Caruna and Calleya (1998), Gerald (2011) and the study conducted by Matata, Elegwa \& Maurice (2014).

This study shows that better reward management was more useful for affective commitment in the organization. The reason behind this was that the faculties were more concerned with the reward management in their organization and they had expected the better reward for them. It could be concluded that better the management of rewards, greater the affective commitment. Higher aggregative mean value of policy and plan and implementation had indicated that policy and plan and implementation of policy and plan were effective than the evaluation and control. On the other 
hand, higher aggregate mean value of affective commitment highlighted that affective commitment was effective in higher education.

\section{REFERENCES}

Angle, H. L., \& Perry, J. L. (1981). An empirical assessment of organizational commitment and organizational effectiveness. Administrative Science Quarterly. 26, 1-14.

Caruna, A. \& Calleya, P. (1998). The effect of internal marketing on organizational commitment among retail bank managers. International Journal of Bank Marketing. MCB University Press.

Chawla, D. \& Sondhi, N. (2011). Research methodology: Concepts \& cases. India: Vikas Publishing House Pvt Ltd.

Dessler, G. (2010). A frame for human resource management. Delhi: Pearson Education.

DeVellis R.F. (2003). Scale development: Theory and applications, ( $2^{\text {nd }}$ ed.). Sage, CA.

Floyd, S.W., \& Wooldridge, R.B. (1994). Dinosaurs or dynamos? Middle management's strategic role. Academy of Management Executive, $8(4), 47-57$.

Gerald, S. (2011). Rrewards and job commitment of primary school teachers in Mityana district. An unpublished master thesis, Arts in educational management, Makerere University.

Guth, W. D. \& Macmillan, I.C. (1986). Strategy implementation versus management self-interest. Journal of Strategic Management.

Iverson, R. D., \& Buttigieg, D. M. (1999). Affective, normative, and continuance commitment: can the 'right kind' of commitment be managed? Journal of Management Studies, 36(3), 307-333.

Kozlowski, J., \& Farr, D. (1988): Employees attitude and competitiveness. Psychological Bulleting, 521, 346-424.

Lawler, E. (1995). The new pay: A strategic approach. Compensation and Benefits Review, 27 (4), 14-22.

Lee, C. H., Yang, C. H., and Hambrick, M. (2012). The relationship between reward system and organizational commitment of fitness club employees in Taiwan; Organizational theory/culture. North American Society for Sport Management Conference.

Malhotra, N., Budhwar, P., \& Prowse, P. (2007). Linking rewards to commitment: An empirical investigation of four UK call centres. International Journal of Human Resource Management. UK. 
March, J., \& Simeon, W. (1958): Organization behaviour. New York: McGrawHill, 43-68.

Matata, K., Elegwa, M., \& Maurice S. (2014). Job-related factors and their influence on organizational commitment of part-time academic staff in institutions of higher education in UK. Journal of Human Resource Management.

Martin, T.N., \& Shawn, O.M. (1984): Predictors of organization commitment. Journal of Vocational Behaviour, 25(3), 270-283.

Meyer, J. P., \& Allen, N. J., (1997). Commitment in the workplace: Theory, research, and application. Thailand, CA: Sage.

Mowday, R.T., Porter, L., \& Steers, R.M. (1982). Effective behaviour in organization. New Jersey: Prentice Hall, 143-161.

Nawab, S., \& Bhatti, K. K. (2011). Influence of employee compensation on organizational commitment and job satisfaction: A case study of educational sector of Pakistan; International Journal of Business and Social Science. Pakistan. 2(8).

Newman, A., \& Sheikh, A. Z. (2012). Organizational commitment in Chinese small and medium sized enterprises: The role of extrinsic, intrinsic and social rewards. The International Journal of Human Resource Management. 23( 2).

Oloko, O. (1972). Impact of management nationality on workers commitment to industrial employment in Nigeria. Journal of Management studies, 9, 21-43.

Omolayo, B., \& Owolabi, A. B. (2007). Monetary reward: A predictor of employees' commitment to medium scale organizations in Nigeria. Bangladesh e-Journal of Sociology. Bangladesh. 4 (1).

Porter, L. M., Steers, R. M., Mowday, R. T., \& Boulian, P. V. (1974). Organizational commitment, job satisfaction, and turnover amongst psychiatric technicians. Journal of Applied Psychology, 59, 603-8.

Porter, L.W.(1968). Managementattitudes and performance. Irwin: Homewood, 50-58.

Rumpel S., \& Medcof, J. W. (2006). Total rewards: Good fit for tech workers; Industrial Research Institute Inc.

Shore, L. M., \& Wayne, S. J. (1993). Commitment and employee behavior: comparison of affective commitment and continuance commitment with perceived organizational support. Journal of Applied Psychology, 78 (5), 774-780.

Tsai, Y., \& Wu, S. W. (2011). Using internal marketing to improve organizational commitment and service quality. Journal of Advanced Nursing. Taiwan. 